\title{
Formation of Dialogic Interactions in Children with Autism Spectrum Disorders
}

\section{Формування діалогічних інтеракцій у дітей з розладами аутистичного спектра}

\author{
Tetiana Skrypnyk \\ Dr. in Psychology, \\ Professor
}

\author{
Тетяна Скрипник \\ доктор психологічних наук, \\ професор
}

E-mail: t.skrypnyk@kubg.edu.ua https://orcid.org/0000-0002-8511-4984

\section{Olga Lozova}

Dr. in Psychology,

Professor

\section{Ольга Лозова}

доктор психологічних наук, професор

\author{
E-mail: o.lozova@kubg.edu.ua \\ https://orcid.org/0000-0002-3549-195X
}

Borys Grinchenko University of Kyiv

$18 / 2$, I. Shamo Str., Kyiv, Ukraine, 02154
Київський університет імені Бориса Грінченка $\triangle$ вул. І. Шамо, 18/2, Київ, Україна, 02154

Original manuscript received November 09, 2019

Revised manuscript accepted March 19, 2020

\begin{abstract}
Introduction. In the course of the presented research, the aim was to identify a group of factors that determine the so-called "inability to dialogue» in children with Autism Spectrum Disorders and to analyze possible ways of forming dialogic interactions in them. Methods. The methods of analysis, systematization, generalization and theoretical triangulation of scientific data have been applied.

Results. As a result of the analysis, problems caused by socio-pragmatic situations were attributed to: difficulties in switching the communicative role of "the speaker»
\end{abstract}


to "the listener»; the lack of positive feedback; alienation from the environment; weakness of communication initiation; monologic manipulability, in which the need to produce a statement is not objectified in the motive and is not realized in the purpose of the statement. Problems associated with psycholinguistic pragmatics include: disturbance of rhythmic-temporal synchronized communication; ignoring partner's speech behavior; linguistic aspects of expression (content and construction of verbal reactions), extralinguistic aspects of expression (gestures, nuances, intonations, emotions); disturbance of the structure of the image and its "sensual tissue»; inability to provide thematic focus of the message; difficulties in forming "verbal networks"; deficiency of socio-pragmatic conclusions (misunderstanding of hidden meanings). The Program of Dialogical Interaction Formation in Children with ASD is proposed as a system of psycho-corrective measures, concluded in accordance with the principles of social orientation, nature compliance and in partnership with the RAS-affected child's family. The program activates mechanisms of reflection, adaptive response and imitation in children with autism (the participants of the dialogue). The content of the components of the Program is structured according to the state of functional limitations of the communication and speech sphere of children with autism, the methods used and the expected results.

Key words: children with autism spectrum disorders, dialogic interactions, speech disorders, psychocorrection.

\section{Вступ}

Провідною умовою повноцінного розвитку дитини є сприятлива соціальна ситуація, яка створює умови для продуктивного спілкування 3 дорослими та враховує досвід позитивної взаємодії 3 однолітками. Ця відома закономірність психічного розвитку у випадку дітей 3 розладами аутистичного спектра (далі - РАС) реалізується надзвичайно важко, оскільки ядерним порушенням психіки таких дітей визначають стійкий дефіцит соціальної комунікації та взаємодії. Відтак, це єдина категорія дітей, яких треба спеціально вчити комунікаційним навичкам: дивитися в обличчя (на очі, губи) співбесідника, наслідувати їх артикуляційні рухи, відгукуватися на звернення, реагувати згодою чи запереченням, звертатися по допомогу чи 3 запитанням, ділитися емоціями тощо.

Згідно 3 Міжнародною класифікацією функціонування обмеження життєдіяльності та здоров’я (МКФ, 2018), яка слугує сучасним орієнтиром для виявлення функційних обмежень дітей 3 
Formation of Dialogic Interactions in Children with Autism...

особливими освітніми потребами, у дітей з РАС визначаються такі типові комунікативні труднощі:

(a) підтримання стосунків 3 дорослими та однолітками;

(б) взаємний обмін думками й ідеями за допомогою усного, писемного, знакового або інших форм мовлення з однією або кількома особами;

(в) отримання інформації про різні об'єкти світу в аспекті їх причинно-наслідкових зв'язків, у відповідь на запитання «чому, де, як»;

(г) розуміння прихованих значень повідомлень усного мовлення та повідомлень, переданих жестами, символами, малюнками;

(д) виконання дій, спрямованих на розуміння та інтерпретацію письмового матеріалу з метою отримання загальних знань або спеціальної інформації тощо (Аппе, 2006).

Основний зміст означених труднощів функціонування свідчить про те, наскільки важко дітям 3 РАС адаптуватись у довкіллі, взаємодіяти та спілкуватися з іншими людей.

Магістральною характерною особливістю мовлення аутичних дітей $\epsilon$ та, що попри збереженість мовленнєвої комунікативнопізнавальної потреби, це мовлення по суті не має комунікативного характеру. Іншими словами, такі діти мають потребу і можуть комунікувати, але не знають як, і це незнання підсилюється тим, що в комунікативній взаємодії вони не орієнтуються на іншу людину. Особливо утруднено етап ініціювання комунікації: багатьом аутичним дітям притаманна нездатність адекватно виражати власні комунікативні наміри, інтенції (прохання, вимоги, коментарі, почуття тощо), використовуючи вербальні та невербальні засоби комунікації (Wetherby \& Rodriques, 1992). Натомість, діти 3 РАC повідомляють про свої наміри невідповідними до ситуації засобами (Watson et al., 1989). Наприклад, прохання може виражатися у формі паралінгвістичних фонаційних засобів (вигуки), а також кінесикогаптичних засобів (падання на підлогу, смикання за одяг тощо). Водночас мовленнєві та екстралінгвістичні засоби в комунікації дітей 3 РАС часто використовуються 3 метою аутостимуляції, що також нівелює комунікативну функцію мовлення. Так, інтенція висловлювання часто виражається у вигляді ехолалії, яка, в силу своєї неочевидної комунікативної спрямованості, може бути кваліфікована як дезадаптивна мовленнєва поведінка. 
Емпірично встановлено, що в аутичних дітей наявні труднощі експресивної, рецептивної комунікації (Kubicek, 1980; Sparling, 1991; Venker, 2014), а саме: (а) недостатня ритміко-часова, синхронізована комунікація; (б) недостатня відповідність експресії обличчя та рухів тіла; (в) відсутність позитивного зворотного зв'язку, необхідного для встановлення взаємодії між матір'ю і дитиною; (г) відсутність диференційованих реакцій у відповідь на певні зміни в поведінці матері.

Соціально-прагматичні труднощі у дітей 3 PAC було пояснено у світлі різноманітних когнітивних теорій (когнітивно орієнтованих прагматичних теорій), таких як Theory of Mind (Happé, 1993; Martin \& McDonald, 2004), теорія слабкого центрального зв’язку (Loukusa, 2018), теорія виконавчої дисфункиії (Hill, 2004), теорія релевантності (Нарре́, 1993; Loukusa et al., 2018), теорія емпатійності-систематизациї (теорія Е-S).

Зокрема, згідно з теорією E-S, С. Барон-Коен (Baron-Cohen, 2009) розмежовує емпатію (Е) й коефіцієнт емпатії (EQ), з одного боку, а з іншого - систематизацію (S) та коефіцієнт здатності до систематизації (SQ). Наукові розвідки С. Барон-Коена дали змогу сформулювати такі специфічні прояви осіб 3 аутизмом, як дефіцит та затримка емпатії у поєднанні з неушкодженою або навіть високорозвиненою здатністю до систематизації (BaronCohen, 2009, 2010; Goldenfeld et al., 2005). У межах теорії E-S це може вказувати на те, що діти з РАС неспроможні впоратися 3 соціально-прагматичними ситуаціями, тому що такі ситуації не відповідають певним передбачуваним уявленням і засвоєним правилам. Усвідомлення стилю обробки інформації особами з РАС важливе як для них самих, так і для їхнього оточення, оскільки труднощі соціально-прагматичного плану впливають на якість життя, погіршуючи взаємодію з однолітками та, в ширшому сенсі, у життєдіяльності в цілому (Loukusa, 2018).

Визначено також, що особливості соціально-прагматичного функціонування осіб 3 РАС залежать від багатьох чинників. Наприклад, можуть бути ситуації, коли вони розпізнають зміст задуму інших людей у питаннях помилкових переконань або окремі контекстуальні подробиці, але не може використовувати ці відомості в ситуаціях, коли змінюються умови або виникають нові обставини 
щодо взаємодії учасників у певній ситуації (Gibbs \& Colston, 2012; Perkins, 2005).

Окремі лінгвістичні та психолінгвістичні спостереження свідчать, зокрема, про те, що синтаксична грамотність висловлювання дітей з РАС може бути на високому рівні (Whyte, Nelson \& Scherf, 2014). Проте, для ширших узагальнень на сьогодні бракує системних психолінгвістичних досліджень мовлення осіб з РАС.

Мета цього дослідження - окреслити шляхи формування у дітей з РАС здатності до діалогічних інтеракцій, що сприятиме покращенню стану їхньої соціальної адаптації та життєвої компетентності.

Мету конкретизовано в таких дослідницьких завданнях:

(1) на основі аналізу спеціальної літератури систематизувати проблематику соціально-прагматичних труднощів дітей 3 аутизмом;

(2) в межах психолінгвістичної прагматики визначити шляхи подолання труднощів діалогічних інтеракцій у дітей 3 аутизмом;

(3) описати та розкрити зміст Програми формування діалогічних інтеракцій дітей з РАС.

\section{Методи дослідження}

У дослідженні застосовано методи аналізу наукових досліджень проблеми, метод систематизації та узагальнення наукових даних. Дослідження предмета відбувалось на методологічній підставі з'ясування відповідності (конгруентності) змісту запропонованих психокорекційних засобів - безпосередньому, «живому» матеріалу вербальної та невербальної комунікації дітей з РАС. 3 огляду на це, замість формальної обробки емпіричних результатів нами презентовано інтуїтивно-логічний аналіз проблеми. Для перевірки й підвищення надійності інтерпретацій застосовувалась процедура теоретичної тріангуляції - використання різних поглядів на інтерпретацію однакових даних, а саме: психолінгвістичний, психологічний підходи та підходи спеціальної психології та педагогіки. 


\section{Результати та дискусії}

Мовленнєва діяльність - це активний, цілеспрямований процес рецепції та/або продукування мовленнєвого повідомлення у взаємодії людей один з одним (Долженков, 2011). Відштовхуючись від соціально-інтерактивної природи висловлювання, М. Бахтін вибудовує на цьому постулаті діалогічну концепцію свідомості, згідно з якою діалог виступає не засобом існування свідомості, а самою сутністю свідомості (Бахтин, 1979).

В центрі нашого дослідження постає такий комунікативний процес, як діалог, що має інтерактивну природу i вимагає від учасників взаємної регуляції багатьох мовленнєвих процесів, кожний з яких впливає на значення, структуру та інші властивості діалогу. Одним з базових недоліків вербальної комунікації у дітей 3 аутизмом визнано нездатність до діалогу (Никольская, Баенская \& Либлинг, 1997; Prizant \& Schuler, 1987; Rutter, 1978). Емпіричним шляхом встановлено, що діти з аутизмом демонструють відсутність позитивного зворотного зв'язку, необхідного для встановлення взаємодії між матір'ю і дитиною, демонструють відсутність диференційованих реакцій у відповідь на незначні зміни в поведінці матері. Також йдеться про те, що у них вже з ранніх етапів розвитку наявні порушення ритміко-часової, синхронізованої комунікації, яка властива нормотиповим дітям (Хаустов, 2008).

Своєю чергою, особливості діалогу визначаються роллю комунікантів у діалогічній взаємодії, що пов'язано 3 виконанням ними певних функцій 3 керування діяльністю партнера й оптимальної організації соціовербальної інтеракції, в цілому. Соціальна взаємність є центральною як у вербальній, так i y невербальній комунікації, i, отже, немає спілкування без соціальної взаємодії (Baron-Cohen, 2009; Vaughan \& Hogg, 2014). Важливим чинником побудови змістовного та послідовного діалогу є орієнтир комунікантів один на одного, що дає можливість здійснити оцінку мовленнєвої поведінки партнера і продовжити діалог відповідним чином з урахуванням специфіки цієї поведінки. Визначено, що ця мовленнєва поведінка зумовлена особливостями міжособистісного сприйняття мовців. Партнер ініціатора, розуміючи суть висловленого i наміри ініціатора, здійснює низку когнітивних операцій, що 
дає йому змогу визначити напрям власного реагування, а саме: унісонних (як згода) або дисонансних (як розбіжність) взаємодій 3 партнером (Хаустов, 2008).

Поряд 3 тим, продуктивність мисленнєво-мовленнєвої діяльності індивіда, зокрема варіативність його мовлення ми пов'язуємо 3 таким психологічним механізмом розвитку пізнавальних здібностей особи, як децентрація. Під час продукування мовлення механізм децентрації стимулює пошукові дії мовця серед тих мовних можливостей, які найбільш адекватного виражають сенс вислову. Детермінантою цього процесу виступає семантична настанова, що розуміється нами як схильність індивіда до актуалізації певних семантичних структур, які містяться в його мовному досвіді (Лозовая, 1990).

На думку U. Frith (1989), в аутичних дітей мають місце труднощі при зміні комунікативної ролі «мовця» на роль «слухача», що $€$ наслідком проблем в інтегруванні значущої інформації. Вочевидь, спостерігаємо ситуацію, яка суперечить відомому положенню М. Бахтіна:

«<..> мовещь налаштований саме на <..> активну зустрічну увагу; він чекає <..> відповіді, згоди, співчуття, заперечення, виконання та ін.» (Бахтин, 1979: 247).

Висловлене про діалог як такий, це судження зайвий раз підкреслює специфічність ситуації діалогічного спілкування в осіб $з$ РAC.

Зрозуміло, що дітям 3 аутизмом, відмітною рисою яких $є$ стійкий дефіцит соціальної комунікації та певна відчуженість від оточення, важко враховувати мовленнєву поведінку партнера. 3 іншого боку, у таких дітей виникають труднощі з продукуванням мовленнєвого висловлення, які виникають при необхідності демонструвати власну мовленнєву поведінку, лінгвістичні (зміст та побудова словесних реакцій) та екстралінгвістичні (жести, акценти, інтонації, емоції) аспекти висловлення, спрямовані на урахування іншої людини заради того, щоб вона зрозуміла мовця. Іншими словами, страждає саме перцептивний бік діалогічного спілкування.

Теорія образу О. Леонтьєва (Леонтьев, 1979) проголошує, що становлення образу формується лише тоді, коли його чуттєва тканина органічно об'єднується зі значенням, тобто коли чуттєве й 
раціональне відображення утворюють єдиний сплав. Інтерпретація проблеми в річищі цієї теорії дає змогу припустити, що у дітей з РАС структуру образу порушено саме в частині структурного компонента «чуттєва тканина». Наше твердження підкріплюється даними клінічних спостережень: зокрема, Б. Мікіртумов і П. Завітаєв пишуть про порушення об'єктивації думки:

«При аутизмі суб'єкт мовлення не вживає слова в їх основному значенні - вказування на предмет, явище, подію. Виражена в словах думка не спрямована на конкретні властивості останніх. Сенс сказаного не відповідає реальності» (Микиртумов \& Завитаев, 2012).

Відтак, цілком логічною постає теза про те, що в діалогічному процесі діти 3 аутизмом не здатні забезпечити тематичну спрямованість інформації (Хаустов, 2008).

У випадку діалогічних інтеракцій осіб 3 РАС також порушується самий принцип інтеракційності діалогічного контакту: вона поступається місцем монологічній маніпулятивності. Розглянемо цю дещо парадоксальну тезу з позиції загальновідомої структури мовленнєвої діяльності, яка складається зі спонукальномотиваційної частини (потреба - мотив - мета); предмета діяльності; відповідності предмета діяльності іiі мотиву; продукту або результату діяльності (Зимняя, 1974). Імовірно, що в діалогічних інтеракціях осіб з РАС потреба говоріння (продукування вислову) не об’єктивується в мотиві, а відтак не усвідомлюється в меті говоріння як певному рівні впливу на інших людей в комунікативній сфері. Оскільки ж необхідність вираження своїх потреб у дитини з РАС зберігається, то маніпулятивна стратегія виявляється майже єдиним способом впливу на поведінку співрозмовника, а також єдиним засобом самокерування, за якого відповіді «об'єкта» маніпуляції потрібні лише для якомога повнішого підвищення впливовості (Арпентьева, 2015).

3 точки зору психофізіології мозку, опанування мовою i продукування мовлення пов'язане 3 формуванням функціональних структур, кожна 3 яких, будучи об'єднана тимчасовими зв'язками, утворює «вербальні мережі» (Ушакова, 1985). Часто повторювані сліди словесних подразників створюються на основі мовлення (мовленнєвих сигналів), що сприймається ззовні, та акумулюють 
мовленнєвий досвід суб'єкта. Оскільки перцептивна функція осіб з РАС порушена (Ковалёв, 1985; Микиртумов \& Завитаев, 2012), то логічно припустити, що труднощі формування «вербальних мереж» відбуваються саме у внутрішньомовленнєвій діяльності цих суб'єктів.

У вербальній взаємодії та ігрових ситуаціях діти 3 РАС рідше за нормотипових однолітків ініціюють комунікацію, дають менше відповідей на запитання, менше спілкуються 3 іншими, використовують стереотипний словниковий запас, можуть висловлювати соціально неприйнятні зауваження (Ruser, 2007). Виявлено також, що діти цієї категорії не розуміють приховані смисли тексту, епітети, ідіоми (Whyte, 2014). За нашими спостереженнями, у дітей з РАС нерідко спостерігаються труднощі розуміння зверненого до них мовлення, що може супроводжуватися проблемною (асоціальною) поведінкою.

Наявні в осіб з РАС утруднення 3 розумінням мовлення, 3 орієнтуванням у контексті мовленнєвої ситуації, 3 продукуванням мовлення, зі продукуванням умовиводів - зазначені проблеми розташовуються в межах наукових інтересів психолінгвістичної прагматики. Підхід до вивчення комунікативно-мовленнєвої діяльності дітей 3 аутизмом, що базується на ідеях прагматики, практикується, наприклад, M. Perkins (2005) зазначає, що процес формування умовиводу залежить від низки пізнавальних дій, таких як увага, запам'ятовування, абстрагування й розв'язання проблем, а також від сприйняття - слухової та візуальної обробки. Наприклад, нездатність виявити іронію, сарказм, образу за поглядом, виразом обличчя, інтонаціями, лексикою, повторами, паузами, акцентами тощо.

У науковій літературі труднощі розуміння сенсу висловлення, метафори, соціальних сценаріїв знайшли своє узагальнення в терміні «дефіциит соиіально-прагматичного висновку» (Dennis, Lazenby \& Lockyer, 2001). У реальних ситуаціях вербальної взаємодії розуміння змісту мовлення та намірів мовця є нелегким процесом (Gibbs \& Colston, 2012; Loukusa, 2018). Прагматичний висновок - це не просто інтерпретація значення або наміри, це постійно мінливий процес адаптації людини до світу (Gibbs \& Colston, 2012). Прагматичні здібності впливають на те, як суб'єкт спілкується і поводиться в соціальних ситуаціях, що, своєю 
чергою, визначає спосіб, яким інші реагують на нього та на його дії. Соціальне сприймання відіграє важливу роль у прагматичному висновку, оскільки для успішного спілкування людині необхідно враховувати емоції, бажання й наміри інших (Loukusa, 2018). Як відомо, особи з РАС не мають сформованої «теорію розуму» (Theory of Mind), завдяки якій одна людина може здогадатися про емоції й наміри іншої людини, поставити себе на її місце (Аппе, 2006).

Згідно 3 науковими дослідженнями (Goldin-Meadow, 2000; Perkins, 2005) можна зробити висновок про те, що для формування діалогічних інтеракцій важливими є як вербальні, так $і$ невербальні компоненти мовлення, такі як жест, погляд, вираз обличчя, поза. Останні, невербальні, компоненти комунікації $\epsilon$ додатковим ресурсом для кодування значення, які разом із мовленням складають інтегровану систему комунікативної сигналізації.

Розглядаємо мовленнєву інтеракцію як послідовність мовленнєвих актів або висловлювань партнерів 3 комунікації. Мовленнєвий акт (мовленнєва дія, мовленнєвий вчинок) вбачається елементарною, мінімальною одиницею мовленнєвої поведінки.

У структурі феномену мовленнєвої інтеракції виокремлюють вербальні та невербальні компоненти (Бердалиева, 2019; Ильина, 2015; Чекулай, 2001 та ін.). Вербальні діалогічні інтеракції, своєю чергою, диференціюються на експресивні та рецептивні. Прикладами експресивних вербальних інтеракцій $є$ вербальна ініціатива (мовець розпочинає діалог, звертається по допомогу, просить припинити певну дію) та адресна передача повідомлення.

Рецептивні вербальні інтеракції - це відповідна реакція мовця на звернене до нього мовлення, вирази спонукального характеру, це відповіді на закриті питання (що передбачають реакцію «так/ні») та на питання особистого характеру. Невербальні інтеракції поділяються на перцептивні та комунікативні підвиди. Перцептивні невербальні інтеракції визначаються тим, що мовець орієнтується на інтонації, вловлює контекст ситуації йі підпорядковує свої прояви цьому контексту (наприклад, у транспорті не розмовляє голосно); орієнтується на знак/жест, орієнтується на мовлення.

У випадку комунікативних невербальних інтеракцій мовець орієнтується на вказівні жести, соціальну посмішку, розподілену увагу, повідомлення через дію (предмети, картки). Усі зазначені вербальні та невербальні інтеракції мають узгоджено генерувати інтерпсихічні 
основи комунікації, і лише тоді ця комунікативна взаємодія триватиме послідовно, логічно й узгоджено між ії учасниками.

Порушення рецептивного мовлення у дітей з РАС пов'язане iз труднощами соціального функціонування: так, вони можуть наслідувати мовлення, при цьому не розуміти його сенс. Дитина 3 такими порушеннями розвитку не демонструє адекватної реакції на вербальні стимули (натомість продукує ехолалії, недиференційовані вокалізації, демонструє відсутність довільної поведінки, тривогу, уникає взаємодії тощо). Експресивне мовлення нерідко буває представлене безпосередніми ехолаліями. Так, дитина повторює поставлене їй запитання, певне слово з фрази звернення до неї (на кшталт, «хочеш?», виокремлене, наприклад, із запитання «ти хочеш їсти?»), фрагмент почутого висловлення, пісні, завченого тексту, шкільного правила, рекламних роликів. Ці мовленнєві прояви частіш за все дитина чинить несвідомо, хоча інколи вони асоціативно пов'язані $з$ наявною ситуацією: наприклад, коли дитина, що почувається ображеною, співає пісню, де йдеться про образу.

Не зайве закцентувати на тому, що у дітей з РАС зберігається мовленнєва комунікативно-пізнавальна потреба, за термінологією I. Зимньої (Зимняя, 2001), проте вона виявляється незвичним чином, що сприяє трактуванню мовленнєво-поведінкових проявів цих дітей як неадекватних. Уникнення вербального спілкування з оточенням, замкненість та ізольованість виникають в результаті того, що дитина набула негативний досвід, коли іiі нездатність зрозуміти мовця приводила до «неприємних» наслідків (роздратування або гнів батьків, покарання за «непослух» тощо). 3 часом зростає ризик дискримінації з боку однолітків та труднощів при інтеграції в суспільство (Loukusa, 2018).

Оскільки специфікою дітей з РАС є функціональні обмеження в соціальній комунікації, то необхідно правильно оцінити соціально-прагматичні навички цих дітей. Така оцінка уможливлює розроблення та планування ефективного втручання.

Переходячи до викладу суті Програми формування діалогічних інтеракиій у дітей з РАC варто актуалізувати два теоретичні постулати, покладені в її основу.

По-перше, Л. Виготський, виходячи з бачення будови вищих психічних функцій як складно структурованої ієрархічної системи, так само системно осмислював порушення психічного розвитку: 
дефект одного 3 елементів системи неминуче впливає на інші елементи системи (Выготский, 1983). Очевидно, що твердження Т. Ушакової про те, що чим більше вираженим $є$ недорозвинення мовлення, тим більш значущі відхилення спостерігаються в розвитку інших психічних функцій (Ушакова, 1979), стосовно дітей 3 РАС справедливе також у зворотному напрямі: відхилення комунікативного розвитку гальмує розвиток їхнє мовлення.

По-друге, слід особливо підкреслити роль мовленнєвої практики у формуванні мовленнєвих навичок. Всі навички (як мовні, так і власне мовленнєві) формуються при кратному виконанні мовленнєвих дій. Здійснення мовленнєвої діяльності передбачає при цьому, що мовні дії повинні бути доведені до такого рівня досконалості їх виконання, як «навичка» (Зимняя, 1974).

Наявні нині практики втручання 3 метою нормалізації стану дітей з РАC, такі, як метод «Exercises» (інтенсивні фізичні вправи та фізичне навантаження), «сенсорно-інтегративна терапія» (Айрес, 2013) та нейродинамічне моделювання руху (Смолянинов, 2011), це практики 3 науково доведеною ефективністю, спрямовані на позитивні зрушення на чинниковому рівні. Використання ресурсів цих методів за умови дотримання фахівцями визначених вимог уможливлює нормалізацію психофізіологічного стану дітей з РАС. Крім цього, у дослідженні (Yoder \& Stone, 2006) доведено, що застосування підходу PECS (система обміну зображеннями для комунікації) було більш успішним щодо збагачення як рецептивного, так і експресивного мовлення, аніж інтенсивне вербальне навчання.

Попри наявні цінні науково- i навчально-методичні напрацювання, спрямовані на дієву підтримку та допомогу дітям 3 РАC, наразі вкрай не достатньо інструментів втручання, що враховували б особливі освітні потреби дітей з РАС дошкільного віку. Позитивні перетворення на комунікативно-мовленнєвому рівні у цих дітей як наслідок комплексного впливу складуть підгрунтя їхнього подальшого навчання й розвитку та уможливлять здобуття ними якісної освіти разом 3 їх нормотиповими однолітками.

\section{Програма формування діалогічних інтеракцій дітей з РАC}

Торкнемось головних принципів реалізації Програми.

Цілісність та закономірність розвитку як цілеспрямованість та послідовність розвитку структурних компонентів психічної 
організації людини. За цим принципом побудови Програми, було враховано послідовні етапи розвитку, а саме те, що вищі психічні функції, до яких належить мовлення, базуються на нижчих, фундаментальних. Тому логічно, що 3 метою нормалізувати діагностовані утруднення у розвитку вищих психічних функцій попередньо мають нормалізуватися базові психічні функції. У розгляді ситуації цілісного розвитку дітей з аутизмом, на нашу думку, доречно спиратися на наукове підгрунтя вищезгаданого сенсорно-інтегративного підходу (Айрес, 2013), адже в результаті наукових досліджень визначено, що у дітей 3 аутизмом через вразливість їхньої психіки, страждають саме фундаментальні сенсорні системи, якими є вестибулярна та пропріоцептивна (Ayres, 1983; Dunn \& Tomchek, 2007 та ін.).

Принщи соиіальної спрямованості має на увазі послідовне формування соціальних функцій дитини, ऑiі здатність до продукування соціально зумовлених інтеракцій.

Природовідповідність як здійснення психолого-педагогічного впливу на аутичних дітей в адекватних культурних контекстах взаємодії - у закладах освіти, вдома, на дитячому майданчику тощо. Діалог є основою комунікації в цих культурних контекстах.

Партнерська взаємодія з родиною дитини з РАС, завдяки якій можна здійснити позитивний вплив на внутрішньородинну ситуацію дитини, а також продумати і узгоджено впроваджувати стратегію втручання у контексті розвитку їі діалогічного мовлення.

Системність нашого підходу полягає у тому, що всю необхідну діяльність у плані нормалізації базових психічних (сенсомоторних) функцій (власне, реалізацію принципу цілісності та закономірності розвитку) ми здійснюємо з опорою на інші із зазначених принципів: соціальну спрямованість, природовідповідність та партнерську взаємодію з родинами дітей з РАС (Скрипник, 2019).

Програма формування діалогічних інтеракцій спрямована на актуалізацію та активізацію таких психічних механізмів, як:

Рерлексія (усвідомлення та здатність до переосмислення себе і продуктів своєї діяльності). Йдеться про використання стану усвідомленості як інструменту для фокусування на подіях теперішнього часу, на змісті того, що відбувається.

Зворотний зв'язок («адаптивна відповідь», за Дж. Айрес). Налагодження цього механізму дає змогу: перетворити спілкування 
на «відкриту систему», що має двосторонній обмін інформацією; досягнути певної «діалоговості» на різних рівнях психічної організації. У цьому сенсі можна говорити про здатність до вербального (словесного) i невербального (тілесного, емоційного контакту, контакту очима, орієнтиру на напрям погляду як розділеної уваги) відгуку.

\section{Наслідування як механізм соціалізації, завдяки якому}

відбувається засвоєння нових форм поведінки, а також усвідомлення сенсу цих дій.

\section{Змістове наповнення Програми представлено у таблиці (табл. 1).}

Таблиця 1. Зміст структурних компонентів Програми формування діалогічних інтеракцій відповідно до стану функціональних обмежень комунікативномовленнєвої сфери дітей з аутизмом

\begin{tabular}{|c|c|c|c|}
\hline № & Функціональні обмеження & Методика & Прогнозований результат \\
\hline 1. & $\begin{array}{l}\text { Брак бажання комунікувати } 3 \\
\text { іншою людиною, дорослою } \\
\text { або дитиною. } \\
\text { Маніпулятивний характер } \\
\text { комунікації (виключно } \\
\text { за власної потреби), яка } \\
\text { здійснюється невідповідним } \\
\text { чином (фрагментарно, } \\
\text { стереотипно, через незвичні } \\
\text { дії, істеричні реакції). }\end{array}$ & $\begin{array}{l}\text { Авторська програма втручання } \\
\text { «Синергія» (система підходів, } \\
\text { спрямованих на нормалізацію } \\
\text { базових психічних функцій): } \\
\text { 1-2 рівні сенсорно- } \\
\text { інтегративної терапії. } \\
\text { Використання емоційно } \\
\text { насиченого мовлення, зміна } \\
\text { тембру, інтонацій з метою } \\
\text { приваблення уваги дитини. }\end{array}$ & $\begin{array}{l}\text { мовано базове почуття } \\
\text { еки та довіри у дитини. } \\
\text { цнуто інтерес до людини. } \\
\text { а досвіду позитивної } \\
\text { цодії з іншою людиною }\end{array}$ \\
\hline 2. & $\begin{array}{l}\text { Ехолалії (повторення слів чи } \\
\text { фраз іншої людини, реклами } \\
\text { тощо), повторення готових } \\
\text { фраз без самостійного } \\
\text { конструювання речень, } \\
\text { труднощі в ініціації та } \\
\text { підтримці діалогу, заміна } \\
\text { займенників. «Застрягання» } \\
\text { на певних звуках, висловах, } \\
\text { запитаннях, текстових } \\
\text { фрагментах пісень, які } \\
\text { при цьому можуть бути } \\
\text { контекстуально пов’язані з } \\
\text { ситуацією спілкування. Брак } \\
\text { використання вербальних } \\
\text { і невербальних засобів } 3 \\
\text { комунікативною метою. }\end{array}$ & $\begin{array}{l}\text { 2-3 рівні сенсорно- } \\
\text { інтегративної терапії. } \\
\text { Метод «Візуальна підтримка» } \\
\text { (візуалізовані правила, } \\
\text { алгоритми комунікативних дій). } \\
\text { Прийом імітування } \\
\text { комунікативних і мовленнєвих } \\
\text { проявів дитини з подальшим } \\
\text { урізноманітненням цих } \\
\text { проявів. } \\
\text { Обігравання стереотипій, } \\
\text { розширення комунікативного } \\
\text { репертуару дитини. } \\
\text { Прийом «слідувати за } \\
\text { інтересами дитини». } \\
\text { Метод обміну картками для } \\
\text { комунікації РЕСS }\end{array}$ & $\begin{array}{l}\text { Розвинена здатність на } \\
\text { елементарному рівні } \\
\text { спілкування та взаємодіяти } \\
\text { з іншими. Поява здатності } \\
\text { використовувати мовлення } \\
\text { відповідно до комунікативної } \\
\text { ситуації. } \\
\text { Поява у дитини: здатності } \\
\text { витримувати емоційні та } \\
\text { фізичні навантаження, } \\
\text { уважності до слів іншої } \\
\text { людини, розумінням мовлення } \\
\text { запам'ятовування, орієнтація } \\
\text { на комунікатора. }\end{array}$ \\
\hline 3 & $\begin{array}{l}\text { Нездатність виявляти } \\
\text { комунікативну ініціативу. } \\
\text { Неадекватність комунікативних } \\
\text { проявів } \\
\text { (коли щось хоче, то бере за } \\
\text { руку іншу людину і тягне }\end{array}$ & $\begin{array}{l}\text { 3-4 рівень сенсорно- } \\
\text { інтегративної терапії. Прийом } \\
\text { зосередження на невербальній } \\
\text { комунікації } \\
\text { Прийом гіпертрофованої } \\
\text { невербальної комунікації. }\end{array}$ & $\begin{array}{l}\text { Розвинуто міжособистісне } \\
\text { сприймання. } \\
\text { Наявна здатність здійснювати } \\
\text { оцінку мовленнєвої поведінки } \\
\text { партнера і продовжити діалог } \\
\text { відповідним чином }\end{array}$ \\
\hline
\end{tabular}


туди, де стоїть бажана річ; при цьому вказівний жест чи людину, відсутні). погляд, звернений на іншу
4. Нездатність підтримувати й завершувати діалог.

Наявність вербальних ритуалів як фіксованої послідовності висловів.
Формування найпростіших жестів («так», «ні») у природних умовах (за потреби - 3 використанням фізичної та вербальної допомоги).

Прийом гіпертрофованого реагування на жести самої дитини. Активізація імітації дитини (наприклад, прості жести: випростовування i розведення рук, плескання у долоні, стискання пальців 3 піднятим до гори великим пальцем «Во!»). Методи: «Терапія $з$ однолітком», «Соціальні історії».

Застосування допоміжних технологій (приладикомунікатори, додатки до планшетів) та візуальної підтримки.

4-й рівень сенсорноінтегративної терапії.

Відпрацювання моделі діалогу: 1) встановлення контакту зі співрозмовником (зоровий, мовленнєвий, тактильний);

2) початок розмови;

3) розвиток теми (реакції партнера та репліки);

4) кінцівка діалогу.

5. Неузгодженість вербальних і невербальних компонентів: Брак правильних інтонацій (наприклад, замість стверджувальних - питальні) Відсутність контролю гучності голосу (може бути стереотипно тихим, або надмірно гучним, напруженим), характерні риси мовлення одноманітність,

Стимулювати міжособистісний розвиток: заняття у парі та мікрогрупі. Метод 3 науково доведеною ефективністю «Терапія $з$ однолітками». Розширення умов для соціального використання мовлення дитиною.

Формування моделей контакту та відпрацьовування їх 3 невиразність, «механістичність», різними людьми - дорослими «скандованість» (штучність, «рубаність»), брак експресії, емоціональна збідненість, маловаріативність. Порушені тон, тембр, ритм мовлення, наголоси у словах та інтонаційні наголоси. Можлива дивність, химерність інтонацій, чужі інтонації (наприклад, інтонації певних персонажів).

\section{та дітьми.}

з урахуванням специфіки цієї поведінки. Закладено підгрунтя розвитку виразного експресивного мовлення

Розвинуто здатність розпочинати та підтримувати діалог, орієнтуватися на вербальні й невербальні прояви іншої людини, підлаштовуючи свої комунікативно-мовленнєві прояви до тематичного та соціально-емоційного контексту.

Досягнуто синтезу вербального і невербального компонентів мовлення Розвинено прагматичний аспект мовлення (здатність до модифікації та застосування мови в залежності від соціального контексту). 
Грамотний супровід дитини з РАС полягає в тому, що фахівець тим чи тим чином звертає іiі увагу на інших, створюючи умови, щоб вона бачила їх, чула, відчувала i розуміла, що саме вони роблять. Такий супровід формує здатність дитини орієнтуватися на іншу людину, наслідувати іiі, розпізнавати емоційні стани та «мову тіла»; поводити себе відповідно до контексту ситуації; помічати й розуміти правильність/неправильність дій. При цьому незамінним $\epsilon$ коректне виконання педагогом функцій супроводу: звертати увагу на інших дітей, надавати імпульс до виконання завдання, використовувати відповідний вид підказки (фізичної, візуальної, вербальної, комбінованої).

Під час корекційних занять 3 метою відпрацювання моделі діалогу формуються інтерактивні реакції дитини на ініціативу 3 боку іншої дитини: відгукуватися на звернення; використовувати соціальну посмішку, слідкувати за поглядом очей, вказівним жестом (розподілена увага), вибачатися та шукати допомогу (за потреби), просити дозволу взяти чужі предмети, дарувати подарунки тощо.

\section{Висновки}

У представленому дослідженні на підставі застосування методів аналізу, систематизації, узагальнення, а також процедур теоретичної тріангуляції наукових даних проаналізовано діалогічні інтеракції дітей 3 розладами аутистичного спектра. Діалог як комунікативний процес інтерактивної природи вимагає від учасників взаємної регуляції низки мовленнєвих та позамовленнєвих психічних процесів. Визначено структуру діалогічних інтеракцій, що охоплює такі блоки, як: вербальний (експресивні й рецептивні) та невербальний (візуальні, перцептивні, емоційні, фізичні) інтеракції.

Логічно доведено, що так звана «нездатність до діалогу» осіб з РАС зумовлюється двома групами чинників. Труднощами, викликаними соціально-прагматичними ситуаціями, визнано: утруднення при зміні комунікативної ролі «мовця» на роль «слухача»; відсутність позитивного зворотного зв'язку; відчуженість від оточення; слабкість ініціювання комунікації; монологічна маніпулятивність, за якої потреба продукування вислову не об'єктивується в мотиві і не усвідомлюється в меті висловлення. 
Труднощами, асоційованими 3 психолінгвістичною прагматикою визнано: порушення ритміко-часової синхронізованої комунікації; ігнорування мовленнєвої поведінки партнера; лінгвістичні аспекти висловлення (зміст та побудова словесних реакцій) екстралінгвістичні аспекти висловлення (жести, акценти, інтонації, емоції) аспекти висловлення; порушення структури образу в частині його «чуттєвої тканини»; нездатність забезпечити тематичну спрямованість повідомлення; труднощі формування «вербальних мереж»; дефіцит соціально-прагматичного висновку (нерозуміння прихованих смислів, тропіки).

Проаналізовано матеріали вербальної та невербальної комунікації дітей з РАС. Окреслено шляхи подолання труднощів діалогічних інтеракцій у дітей 3 аутизмом. Необхідно починати корекцію порушень розвитку мовлення 3 корекції комунікативного розвитку та правильної оцінки соціально-прагматичних навичок дитини. Всі навички (як мовні, так і власне мовленнєві) формуються при кратному виконанні мовленнєвих дій.

Запропоновано Програму формування діалогічних інтеракиій y дітей з розладами аутистичного спектра як систему психокорекційних засобів, укладену згідно з принципами соиіальної спрямованості, природовідповідності, партнерської взаємодії $з$ родиною дитини з РАC. Програма активізує у психіці учасників механізми рефлексї, адаптивної відповіді та наслідування. Зміст структурних компонентів Програми структуровано відповідно до стану функціональних обмежень комунікативномовленнєвої сфери дітей 3 аутизмом, застосовуваних методик та очікуваних результатів.

Перспективи подальших досліджень. Запропонована Програма охоплює систематизовані та вибудувані за науково обгрунтованим алгоритмом дієві практики допомоги особам з РАС, які визнані в межах міжнародного досвіду та професійного досвіду авторів цієї розвідки. Подальші дослідницькі зусилля будуть спрямовані на доведення ефективності Програми. Передбачаємо, що реалізація Програми матиме вплив на цілісний розвиток дітей 3 розладами аутистичного спектра, і в цьому контексті сприятиме становленню у них здатності до діалогічної взаємодії як необхідної умови соціальної адаптації та життєвої компетентності. 


\section{Література}

Айрес, Дж. (2013). Ребенок и сенсорная интеграция. Понимание скрытых проблем развития. Москва: Теревинф.

Аппе, Фр. (2006). Введение в психологическую теорию аутизма. Д.В. Ермолаева (Перевод). Москва: Теревинф.

Арпентьева, М.Р. (2015). Ожидания и игры: диалогическое и монологическое общение. Социальные явления, 3, 32-40.

Бахтин, М.М. (1979). Эстетика словесного творчества. Москва: Искусство.

Бердалиева, Р.Ш. (2019). Ментальные различия коммуникантов в процессе невербального общения. Проблемы современной науки и образования, 5 (138), 46-49.

Выготский, Л.С. (1983). Основы дефектологии. Собрание сочинений (Т. 1-6). (Т. 5). Москва: Педагогика.

Долженков, В.Н. (2011). Семантико-прагматические характеристики словесной оценки речевого поведения партнера в диалоге: на материале английского и русского языков. Дисс. канд. психол. наук. Москва.

Зимняя, И.А. (2001). Лингвопсихология речевой деятельности. Москва: Москов. психолого-социал. ин-т; Воронеж: МОДЭК.

Зимняя, И.А. (1974). Речевая деятельность и психология речи. А.А. Леонтьев (Ред.), Основы теории речевой деятельности (с. 64-72). Москва: Наука, .

Ильина, И.Е. (2015). Основные подходы к изучению невербальных средств коммуникации. Научный альманах Тамбовского государственного университета, 3, 211-221.

Ковалев, В.В. (1985). Семиотика и диагностика психических заболеваний у детей и подростков. Москва: Медицина.

Леонтьев, А.Н. (1979). Психология образа. Вестник МГУ. Психология, 2, 3-13.

Лозовая, О.Н. (1990). Психологический анализ реноминативных процессов в речевом мышлении (на материале профессиональной речи учителя). Дисс. канд. психол. наук. Киев.

Микиртумов, Б., \& Завитаев, П. (2012). Аутизм: история вопроса и современный взгляд. Санкт-Петербург: Н-Л.

Міжнародна класифікація функиіонування, обмежень життєдіяльності та здоров'я: МКФ. (2018). Дані каталогізації публікацій бібліотечної служби BO3. Режим доступу: https://moz.gov.ua/uploads/1/5262-dn_20180523_981_ dod_1.pdf

Никольская, О.С., Баенская, Е.Р., \& Либлинг, М.М. (1997). Аутичный ребенок: Пути помощи. Москва: Теревинф.

Скрипник, Т.В. (2019). Діти з аутизмом в інклюзї: сценарії успіху. Київ: Київ. ун-т ім. Б. Грінченка.

Смолянинов, А.Г. (2011). Нейрокинезитерапия. Рука - мозг. Киев: Пресс-КИТ.

Ушакова, Т.Н. (1985). Проблема внутренней речи в психологии и психофизиологии. Психологические и психофизиологические исследования речи (с. 13-26). Москва: Наука.

Ушакова, Т.Н. (1979). Функичиональные структуры второй сигнальной системы. Психофизиологические механизмы речи. Москва: Наука.

Хаустов, А.В. (2008). Развитие речевой коммуникации у детей с аутистическими нарушениями. Детский аутизм: исследования и практика (с. 208-235). Москва: Образование и здоровье. 
Чекулай, О.П. (2001). Основи, розвиток та перспективи аналізу вербальних інтеракцій. Вісник Запорізького державного університету, 3, 67-73.

Ayres, A.J. (1983). Sensory Integration and Learning Disorders. Los Angeles, CA, Western Psychological Services.

Baron-Cohen, S. (2009). Autism: The empathising-systemising (E-S) theory. Annals of the New York Academy Sciences, 1156, 68-80. https://doi.org/10.1111/j.17496632.2009.04467.x

Dennis, M., Lazenby, A.L., \& Lockyer, L. (2001). Inferential lan-guage in highfunctioning children with autism. Journal of Autism and Developmental Disorders, 31, 147-154. https://doi:10.1023/A:1005661613288

Frith, U. (1989). Autism: explaining the enigma. Oxford, UK: Blackwell.

Gibbs, R.W.Jr., \& Colston, H.L. (2012). Interpreting figurative meaning. Cambridge University Press. https://doi.org/10.1017/CBO9781139168779

Goldenfeld, N., Baron-Cohen, S., \& Wheelwright, S. (2005). Empathizing and systemizing in males, females and autism. Clinical Neuropsychiatry, 2, 338-345. https://doi.org/10.1017/CBO9780511543753.019

Goldin-Meadow, S. (2000). Beyond Words: The Importance of Gesture to Researchers and Learners. Child Development, 71 (1), 231-239. https://doi.org/10.1111/14678624.00138

Happé, F. (1993). Communicative competence and theory of mind in autism a test of Relevance theory. Cognition, 48, 101-109. https://doi.org/10.1016/00100277(93)90026-R

Hill, E.L. (2004). Evaluating the theory of executive dysfunction in autism. Developmental Review, 24 (2), 189-233. https://doi.org/10.1016/j.dr.2004.01.001

Kubicek, L.F. (1980). Organization in two mother-infant interactions involving a normal infant and his fraternal twin brother who was later diagnosed as autistic. In T. Field, S. Goldberg, D. Stein \& A. Sostek (Eds.), High risk infants and children: Adult and peer interactions (pp. 99-110). New York: Academic press.

Loukusa, S., Mäkinen, L., Kuusikko-Gauffin, S., Ebeling, H., \& Leinonen, E. (2018). Assessing social-pragmatic inferencing skills in children with autism spectrum disorder. Journal of Communication Disorders, 73, 91-105. https://doi. org/10.1016/j.jcomdis.2018.01.006

Martin, I., \& McDonald, S. (2004). An exploration of causes of non-literal language problems in individuals with Asperger syndrome. Journal of Autism and Developmental Disorders, 34, 311-328. https://doi.org/10.1023/ B:JADD.0000029553.52889.15

Perkins, M.R. (2005). Pragmatic ability and disability as emergent phenomena Clinical Linguistics and Phonetics, $19(5), \quad 367-377 . \quad \mathrm{https} / / /$ doi. org/10.1080/02699200400027155

Prizant, B.M., \& Schuler, A.L. (1987). Facilitating communication: Language approaches. In D.J. Cohen \& A.M. Donnellan (Eds.), Handbook of Autism and Pervasive Developmental Disorders (pp. 289-300). New York: Wiley.

Ruser, T.F., Arin, D., Dowd, M., Putnam, S., Winklosky, B., Sheidley, B.R., ... Folstein, S. (2007). Communicative Competence in Parents of Children with Autismand Parents of Children with Specific Language Impairment. Journal of Autism and Developmental Disorders, 37, 1323-1336. https://doi.org/10.1007/ s10803-006-0274-z

Rutter, M. (1978). Diagnosis and definitions of childhood autism. Journal of Autism \& Childhood Schizophrenia, 8 (2), 139-161. https://doi.org/10.1007/BF01537863 
Sparling, J.W. (1991). A prospective case report of infantile autism from pregnancy to four years. Journal of Autism and Developmental Disorders, 21 (2), 229-236. https://doi.org/10.1007/BF02284762

Tomblin, B., Tager-Flusberg, H., \& Folstein, S. (2007). Communicative competence in parents of children with autism and parents of children with specific language impairment. Journal of Autism and Developmental Disorders, 37 (6), 1323-1336. https://doi.org/10.1007/s10803-006-0274-z

Tomchek, S.D., \& Dunn, W. (2007). Sensory Processing in Children With and Without Autism: A Comparative Study Using the Short Sensory Profile. American Journal of Occupational Therapy, 61, 190-200. https://doi.org/10.5014/ajot.61.2.190

Vaughan, G.M., \& Hogg, M.A. (2014). Social psychology (7 ${ }^{\text {th }}$ ed.). Australia: Pearson Education: Frenchs Forest.

Venker, C.E. (2014). Statistical word learning and non-social visual attention in children with autism. Doctor's thesis. Madison, Wisconsin: University of Wisconsin-Madison.

Watson, L., Lord, C., Schaffer, B., \& Schopler, E. (1989). Teaching spontaneous communication to autistic and developmentally handicapped children. New York: Irvington.

Wetherby, A.M., \& Rodriguez, G.P. (1992). Measurement of communicative intentions in normally developing children during structured and unstructured contexts. Journal of Speech \& Hearing Research, 35 (1), 130-138. https://doi.org/10.1044/ jshr.3501.130

Whyte, E.M., Nelson, K.E., \& Scherf, K.S. (2014). Idiom, Syntax, and Advanced Theory of Mind Abilities in Children With Autism Spectrum Disorders. Journal of Speech, Language, and Hearing Research, 57, 120-130. https://doi. org/10.1044/1092-4388(2013/12-0308)

Yoder, P., \& Stone, W.L. (2006). A Randomized Comparison of the Effect of Two Prelinguistic Communication Interventions on the Acquisition of Spoken Communication in Preschoolers With ASD. Journal of Speech, Language, and Hearing Research, 49 (4), 698-711. https://doi.org/10.1044/1092-4388(2006/051)

\section{References}

Ayres, J.Dzh. (2013). Rebenok i sensornaya integratsiya. Ponimaniye skrytykh problem razvitiya [Child and sensory integration. Understanding the hidden development challenges]. Moscow: Terevinf [in Russian].

Appe, Fr. (2006). Vvedeniye v psikhologicheskuyu teoriyu autizma [Introduction to the Psychological Theory of Autism]. In D.V. Ermolayeva (Translation). Moscow: Terevinf [in Russian].

Arpentyeva, M.R. (2015). Ozhidaniya i igry: dialogicheskoye i monologicheskoye obshcheniye [Expectations and games: dialogic and monologic communication]. Sotsialnyye yavleniya - Social phenomena, 3, 32-40 [in Russian].

Bakhtin, M.M. (1979). Estetika slovesnogo tvorchestva [Aesthetics of verbal creativity]. Moscow: Iskusstvo [in Russian].

Berdaliyeva, R.Sh. (2019). Mentalnyye razlichiya kommunikantov v protsesse neverbalnogo obshcheniya [Mental differences of communicants in the process of non-verbal communication]. Problemy sovremennoy nauki i obrazovaniya Problems of modern science and education, 5 (138), 46-49 [in Russian]. 
Vygotskiy, L.S. (1983). Osnovy defektologii [The basics of defectology]. In A.V. Zaporozhec (Ed.), Sobraniye sochineniy - Collected works. (Vols. 1-6). (Vol. 5). Moscow: Pedagogika. [in Russian].

Dolzhenkov, V.N. (2011). Semantiko-pragmaticheskiye kharakteristiki slovesnoy otsenki rechevogo povedeniya partnera $\mathrm{v}$ dialoge : na materiale angliyskogo $\mathrm{i}$ russkogo yazykov [Semantic and pragmatic characteristics of verbal assessment of the partner's speech behavior in the dialogue: on the material of English and Russian languages]. Candidate's thesis. Moscow [in Russian].

Zimnyaya, I.A. (2001). Lingvopsikhologiya rechevoy deyatelnosti [Linguopsychology of speech activity]. Moscow: Moskovskij psihologo-socialnyj institut; Voronezh: MODEK [in Russian].

Zimnyaya, I.A. (1974). Rechevaya deyatelnost i psikhologiya rechi [Speech activity and speech psychology]. In A.A. Leontev (Ed.), Osnovy teorii rechevoy deyatelnosti - Fundamentals of the theory of speech activity (pp. 64-72). Moscow: Nauka [in Russian].

Ilina, I.E. (2015). Osnovnyye podkhody $\mathrm{k}$ izucheniyu neverbalnykh sredstv kommunikatsii [The main approaches to the study of non-verbal means of communication]. Nauchnyy almanakh Tambovskogo gosudarstvennogo universiteta Scientific Almanac of Tambov State University, 3, 211-221 [in Russian].

Kovalev, V.V. (1985). Semiotika $i$ diagnostika psikhicheskikh zabolevaniy u detey $i$ podrostkov [Semiotics and diagnosis of mental illness in children and adolescents]. Moscow: Meditsina [in Russian].

Leontyev, A.N. (1979). Psikhologiya obraza [The psychology of the image]. Vestnik MGU. Psikhologiya - Bulletin of Moscow State University. Psychology, 2, 3-13 [in Russian].

Lozovaya, O.N. (1990). Psikhologicheskiy analiz renominativnykh protsessov v rechevom myshlenii (na materiale professionalnoy rechi uchitelya) [Psychological analysis of renominative processes in speech thinking (based on the material of a teacher's professional speech)]. Candidate's thesis. Kiyev [in Russian].

Mikirtumov, B., \& Zavitayev, P. (2012). Autizm: istoriya voprosa $i$ sovremennyy vzglyad [Autism: A Background and a Modern Look]. St. Peterburg: N-L [in Russian].

Mizhnarodna klasyfikatsiia funktsionuvannia, obmezhen zhyttiediialnostita zdorovia: MKF [International Classification of Functioning, Life Constraints and Health: ICF]. (2018). Dani katalohizatsii publikatsij bibliotechnoi sluzhby VOZ Cataloging of WHO Library Service publications]. Retrieved from: https://moz. gov.ua/uploads/1/5262-dn_20180523_981_dod_1.pdf [in Ukrainian].

Nikolskaja, O.S., Baenskaja, E.R., \& Libling, M.M. (1997). Autichnyj rebenok: Puti pomoshhi [Autistic child: Ways of help]. Moscow: Terevinf [in Russian].

Skrypnyk, T.V. (2019). Dity z autyzmom v inkliuzii: stsenarii uspikhu [Children with Autism in Inclusion: Success Scenarios]. Kyiv: Kyiv. un-t im. B. Hrinchenka [in Ukrainian].

Smolyaninov, A.G. (2011). Neyrokineziterapiya. Ruka - mozg [Neurokinesitherapy. The hand is the brain]. Kyiv: Press-KIT [in Russian].

Ushakova, T.N. (1985). Problema vnutrenney rechi v psikhologii i psikhofiziologii. [The problem of internal speech in psychology and psychophysiology]. Psikhologicheskiye i psikhofiziologicheskiye issledovaniya rechi - Psychological and psychophysiological studies of speech (pp. 13-26). Moscow: Nauka [in Russian]. 
Ushakova, T.N. (1979). Funktsionalnyye struktury vtoroj signalnoy sistemy. Psikhofiziologicheskiye mekhanizmy rechi [Functional structures of the 2nd signal system. Psychophysiological mechanisms of speech]. Moscow: Nauka [in Russian].

Khaustov, A.V. (2008). Razvitiye rechevoy kommunikatsii u detey s autisticheskimi narusheniyami [The development of verbal communication in children with autistic disorders]. Detskiy autizm: issledovaniya i praktika - Childhood Autism: Research and Practice (pp. 208-235). Moscow: Obrazovaniye i zdorovye [in Russian].

Chekulaj, O.P. (2001) Osnovy, rozvytok ta perspektyvy analizu verbal'nykh interaktsij [Fundamentals, development and perspectives of analysis of verbal interactions]. Visnyk Zaporizkoho derzhavnoho universytetu - Bulletin of Zaporizhzhya State University, 3, 67-73 [in Ukrainian].

Ayres, A.J. (1983). Sensory Integration and Learning Disorders. Los Angeles, CA, Western Psychological Services.

Baron-Cohen, S. (2009). Autism: The empathising-systemising (E-S) theory. Annals of the New York Academy Sciences, 1156, 68-80. https://doi.org/10.1111/j.17496632.2009.04467.x

Dennis, M., Lazenby, A.L., \& Lockyer, L. (2001). Inferential lan-guage in highfunctioning children with autism. Journal of Autism and Developmental Disorders, 31, 147-154. https://doi:10.1023/A:1005661613288

Frith, U. (1989). Autism: explaining the enigma. Oxford, UK: Blackwell.

Gibbs, R.W.Jr., \& Colston H.L. (2012). Interpreting figurative meaning. Cambridge University Press. https://doi.org/10.1017/CBO9781139168779

Goldenfeld, N., Baron-Cohen, S., \& Wheelwright, S. (2005). Empathizing and systemizing in males, females and autism. Clinical Neuropsychiatry, 2, 338-345. https://doi.org/10.1017/CBO9780511543753.019

Goldin-Meadow, S. (2000). Beyond Words: The Importance of Gesture to Researchers and Learners. Child Development, 71 (1), 231-239. https://doi.org/10.1111/14678624.00138

Happé, F (1993) Communicative competence and theory of mind in autism a test of Relevance theory. Cognition, 48, 101-109. https://doi.org/10.1016/00100277(93)90026-R

Hill, E.L. (2004). Evaluating the theory of executive dysfunction in autism. Developmental Review, 24 (2), 189-233. https://doi.org/10.1016/j.dr.2004.01.001

Kubicek, L.F. (1980). Organization in two mother-infant interactions involving a normal infant and his fraternal twin brother who was later diagnosed as autistic. In T. Field, S. Goldberg, D. Stein \& A. Sostek (Eds.), High risk infants and children: Adult and peer interactions (pp. 99-110). New York: Academic press.

Loukusa, S., Mäkinen, L., Kuusikko-Gauffin, S., Ebeling, H., \& Leinonen, E. (2018). Assessing social-pragmatic inferencing skills in children with autism spectrum disorder. Journal of Communication Disorders, 73, 91-105. https://doi. org/10.1016/j.jcomdis.2018.01.006

Martin, I., \& McDonald, S. (2004). An exploration of causes of non-literal language problems in individuals with Asperger syndrome. Journal of Autism and Developmental Disorders, 34, 311-328. https://doi.org/10.1023/ B:JADD.0000029553.52889.15

Perkins, M.R. (2005). Pragmatic ability and disability as emergent phenomena Clinical Linguistics and Phonetics, 19 (5), 367-377. https://doi.org/10.1080/02699200400027155 
Prizant, B.M., \& Schuler, A.L. (1987). Facilitating communication: Language approaches. In D.J. Cohen \& A.M. Donnellan (Eds.), Handbook of Autism and Pervasive Developmental Disorders (pp. 289-300). New York: Wiley.

Ruser, T.F., Arin, D., Dowd, M., Putnam, S., Winklosky, B., Sheidley, B.R., ... Folstein, S. (2007). Communicative Competence in Parents of Children with Autismand Parents of Children with Specific Language Impairment. Journal of Autism and Developmental Disorders, 37, 1323-1336. https://doi.org/10.1007/ s10803-006-0274-z

Rutter, M. (1978). Diagnosis and definitions of childhood autism. Journal of Autism \& Childhood Schizophrenia, 8 (2), 139-161. https://doi.org/10.1007/BF01537863

Sparling, J.W. (1991). A prospective case report of infantile autism from pregnancy to four years. Journal of Autism and Developmental Disorders, 21 (2), 229-236. https://doi.org/10.1007/BF02284762

Tomblin, B., Tager-Flusberg, H., \& Folstein, S. (2007). Communicative competence in parents of children with autism and parents of children with specific language impairment. Journal of Autism and Developmental Disorders, 37 (6), 1323-1336. https://doi.org/10.1007/s10803-006-0274-z

Tomchek, S.D., \& Dunn, W. (2007). Sensory Processing in Children With and Without Autism: A Comparative Study Using the Short Sensory Profile. American Journal of Occupational Therapy, 61, 190-200. https://doi.org/10.5014/ajot.61.2.190

Vaughan, G.M., \& Hogg, M.A. (2014). Social psychology (7 ${ }^{\text {th }}$ ed.). Australia: Pearson Education: Frenchs Forest.

Venker, C.E. (2014). Statistical word learning and non-social visual attention in children with autism. Doctor's thesis. Madison, Wisconsin: University of Wisconsin-Madison.

Watson, L., Lord, C., Schaffer, B., \& Schopler, E. (1989). Teaching spontaneous communication to autistic and developmentally handicapped children. New York: Irvington.

Wetherby, A.M., \& Rodriguez, G.P. (1992). Measurement of communicative intentions in normally developing children during structured and unstructured contexts. Journal of Speech \& Hearing Research, 35 (1), 130-138. https://doi.org/10.1044/ jshr.3501.130

Whyte, E.M., Nelson, K.E., \& Scherf, K.S. (2014). Idiom, Syntax, and Advanced Theory of Mind Abilities in Children With Autism Spectrum Disorders. Journal of Speech, Language, and Hearing Research, 57, 120-130. https://doi. org/10.1044/1092-4388(2013/12-0308)

Yoder, P., \& Stone, W.L. (2006). A Randomized Comparison of the Effect of Two Prelinguistic Communication Interventions on the Acquisition of Spoken Communication in Preschoolers With ASD. Journal of Speech, Language, and Hearing Research, 49 (4), 698-711. https://doi.org/10.1044/1092-4388(2006/051)

\section{АНОТАЦІЯ}

Вступ. У ході представленого дослідження переслідувалась мета виявити групу чинників, які зумовлюють так звану "нездатність до діалогу» у дітей з розладами аутистичного спектра (РАC) та проаналізувати шляхи формування у них діалогічних інтеракції. 
Методи. Застосовано методи аналізу, систематизації, узагальнення та теоретичної тріангуляції наукових даних.

Результати. В результаті аналізу до проблем, викликаних соціальнопрагматичними ситуаціями, було віднесено: утруднення при зміні комунікативної ролі “мовця» на роль "слухача»; відсутність позитивного зворотного зв'язку; відчуженість від оточення; слабкість ініціювання комунікаціі; монологічна маніпулятивність, за якої потреба продукування вислову не об'єктивується в мотиві і не усвідомлюється в меті висловлення. До проблем, асоційованих із психолінгвістичною прагматикою, віднесено: порушення ритміко-часової синхронізованої комунікації; ігнорування мовленнєвої поведінки партнера; лінгвістичні аспекти висловлення (зміст та побудова словесних реакцій), екстралінгвістичні аспекти висловлення (жести, акцентування, інтонації, емоціі); порущення структури образу в частині його "чуттєвої тканини»; нездатність забезпечити тематичну спрямованість повідомлення; труднощі фрормування "вербальних мереж»; дефіцит соціально-прагматичного висновку (нерозуміння прихованих смислів, тропіки). Запропоновано Програму формування діалогічних інтеракцій у дітей з розладами аутистичного спектра як систему психокорекційних засобів, укладену згідно з принципами соціальної спрямованості, природовідповідності, партнерської взаємодії з родиною дитини з РАС. Програма активізує у психіці дітей з аутизмом - учасників діалогу - механізми реслексії, адаптивноі відповіді та наслідування. Зміст структурних компонентів Програми структуровано відповідно до стану функціональних обмежень комунікативномовленнєвої срери дітей з аутизмом, застосовуваних методик та очікуваних результатів.

Ключові слова: діти з розладами аутистичного спектра, діалогічні інтеракції, порушення мовлення, психокорекція.

\section{Скрыпник Татьяна \& Лозовая Ольга. Формирование диалогических интеракций у детей с расстройствами аутистичного спектра}

\section{АННОТАЦИЯ}

Введение. В ходе представленного исследования преследовалась цель выявить группу факторов, обусловливающих т. н. "неспособность к диалогу» у детей с расстройствами аутистического спектра (РАC) и проанализировать пути формирования у них диалогчческих интеракции.

Методы. Применены методы анализа, систематизации, обобщения и теоретической триангуляции научных данных.

Результаты. В результате анализа к проблемам, вызванным социальнопрагматическими ситуациями, были отнесены: затруднения при изменении коммуникативной роли "говорящего» на роль "слушателя»; отсутствие положительной обратной связи; отчужденность от окружающих; слабость инициирования коммуникации; монологическая манипулятивность, при которой потребность продуцирования речи не объективируется в мотиве 
и не осознается в цели высказывания. К проблемам, ассоциированным с психолингвистической прагматикой, отнесены: нарушение ритмико-временной синхронизированной коммуникации; игнорирование речевого поведения партнера; лингвистические аспекты высказывания (содержание и построение словесных реакций), экстралингвистические аспекты высказывания (жесты, акцентирование, интонации, эмоции); нарушение структуры образа в части его "чувственной ткани»; неспособность обеспечить тематическую направленность сообщения; трудности формирования "вербальных сетей»; дефичит социально-прагматического вывода (непонимание скрытых смыслов, тропики). Предложена Программа формирования диалогических интеракций у детей с расстройствами аутистического спектра как система психокоррекционных средств, структурированную в соответствии с принципами социальной направленности, природосообразности, партнерского взаимодействия с семьей ребенка с РАС. Программа активизирует в психике детей с аутизмом - участников диалога - механизмы рефлексии, адаптивного ответа и подражания. Содержание структурных компонентов Программы согласовано с состоянием функциональных ограничений коммуникативноречевой сферы детей с аутизмом, применяемых методик и ожидаемых результатов.

Ключевые слова: дети с расстройствами аутистического спектра, диалогические интеракции, нарушения речи, психокоррекция. 